\title{
The Market For The "Not-So-Rare" Rare Earth Elements
}

\author{
Joseph A. Giacalone, St. John's University, USA
}

\begin{abstract}
This paper examines the market for the Rare earth elements. These are comprised of 17 elements of the periodic table which include 15 elements from the group known as lanthanides and two additional elements known as scandium and yttrium. The metals are often found combined together in ores and must be separated into its individual elements. The fact is that rare earth metals are not rare in terms of the quantity present in the earth's crust. However, the metals are less concentrated than other more common metals and the extraction and separation processes necessitate high research and development costs and large capital outlays.
\end{abstract}

The various applications of rare earth elements can be broadly classified into four major categories, namely: High Technology Consumer Products, Environmentally Friendly Products, Industrial and Medical Devices, and National Defense Systems. The demand for such high technology products is rapidly increasing causing a simultaneous upsurge in the demand for rare earth metals as well.

On the supply side, China dominates the production rare earth elements, mining approximately 97\% of total world production. Consequently, most countries must rely on imports of these REEs to facilitate production of the various systems and products that are dependent on the rare earth metals as raw materials. This near-monopoly imposes several supply-chain risks on the importing nations which are exploring ways to mitigate the potential economic harm associated with these risks.

Keywords: Rare Earth Elements; Lanthanides; Scandium; Yttrium

\section{INTRODUCTION}

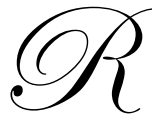

are earth elements are comprised of 17 elements of the periodic table which include 15 elements from the group known as lanthanides and two additional elements known as scandium and yttrium. The lanthanides are comprised of the elements ranging from atomic number 57 to 71 and include: lanthanum, cerium, praseodymium, neodymium, promethium, samarium, europium, gadolinium, terbium, dysprosium, holmium, erbium, thulium, ytterbium, and lutetium. These elements are usually found combined together in ores that require complex separation techniques to isolate the individual elements. The metals are known to exhibit very powerful magnetic and electrical properties that are very useful in many of the products that we rely on today.

Despite the connotation suggested by its name, rare earth metals are actually not rare at all in terms of the quantity present in the earth's crust. In fact, a number of these elements, such as cerium and yttrium are more abundant within the earth's surface than are more commonly known metals such as gold, silver, iron or copper. What makes these rare earth elements scarce are the difficulties presented in mining and extracting these metals from its ore, and separating the metals into their individual elements -- processes that incur a great deal of research and development costs, high capital outlays, and require a highly trained and specialized work force. The reason that these processes are exceptionally difficult is attributed to the fact that, unlike the more familiar metals like gold and silver which can be found in high concentrations within the earth's crust, the deposits of REEs are much less dense making it difficult and sometimes economically impractical to extract. Most deposits contain 1\% or less of rare earth elements, with the world's "richest veins" of deposits consisting of only $4 \%$ to $9 \%$ of the elements (Service, 2010b). 


\section{APPLICATIONS OF RARE EARTH METALS THAT ARE DRIVING DEMAND}

Although the average American consumer may not be acutely aware of the vital role that rare earth elements play in our everyday lives, the growing demand for more technologically advanced and environmentally friendly products has made the role of these rare earth minerals increasingly critical. The various applications of rare earth elements can be broadly classified into four major categories, namely: High Technology Consumer Products, Environmentally Friendly Products, Industrial Applications and National Defense Systems. Figure 1 shows the usage distribution of rare earth minerals in 2008 as outlined by the United States Geological Survey (2010).

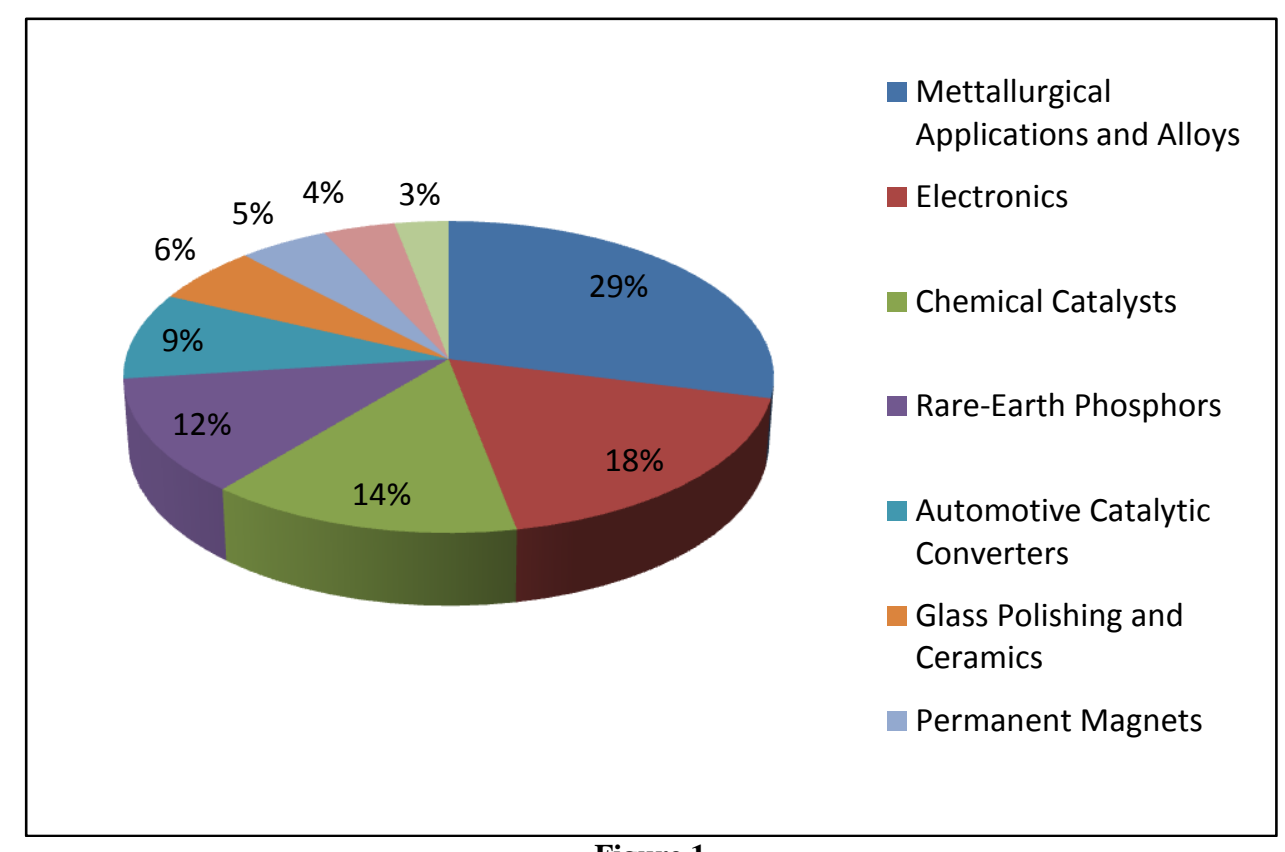

Figure 1

Distribution Of Rare Earths As Of 2008

Source: Salazar, K., \& McNutt, M. K. (2010). Minerals Commodity Summaries 2010. Washington: United States Government Printing Office, 128.

\section{High Technology Consumer Products}

A large number of what we consider to be "technologically advanced" products, such as cellular phones, flat panel display screens used in television sets and laptops, and computer hard drives, rely on the of application rare earth elements. These commodities are sometimes referred to as Rare Earth Dependent Technologies (REDT) for two reasons. The first reason is that these high-tech products are not considered to be "commercially viable" without the use of rare earth elements, and the second reason is that there are currently no technically feasible alternatives for REEs to be used in these so called REDTs (Molycorp Minerals , 2009).

\section{Environmentally Friendly Products}

As concerns grow over the state of the environment and the depletion of the earth's non-renewable resources such as oil and coal, there is increased pressure on companies to provide consumers with more environmentally friendly products such as hybrid and electric vehicles and energy efficient florescent light bulbs. Furthermore, a great deal of urgency is being placed on the government to provide the necessary funding to support research and development on renewable sources of energy such as wind turbines and solar panels. It so happens that the permanent magnets and batteries that are implemented in hybrid and electric vehicles, as well as the generators used to power wind turbines, are heavily dependent on the employment rare earth minerals. According to 
Service(2010b), a single Toyota Prius, a well known hybrid vehicle, "uses a kilogram of neodymium for its electric engine and 10 kilograms of lanthanum for its nickel metal hydride battery" (p. 1597). Wind turbines are also significant users of rare earth metals (Bourzac 2011).

Some may plausibly argue, however, that the use of rare earth elements to produce environmentally friendly products may be somewhat counterintuitive because the process of mining the metals may actually harm the environment. The tailings that are produced in the mining process are highly toxic and require careful handling and disposal. However, at this time, effective alternative materials have not been developed (Bourzac 2011).

\section{National Defense Systems}

Rare earth elements play an extremely crucial role in a myriad of national defense mechanisms used by the United States Department of Defense (DoD). According to the 2010 Congressional Research Service Report for Congress "the primary defense application of rare earth materials is their use in four types of permanent magnet materials commercially available: Alnico, Ferrites, Samarium Cobalt, and Neodymium Iron Boron" (Humphries, 2010). The report describes these magnets as "one of the world's strongest permanent magnets and an essential element to many military weapon systems" (p. 4). A wide array of weapon systems depend on the power supplied by these rare earth magnets include missile guidance systems, smart bombs, underwater mine detection systems, defense system control panels, optical equipment, antimissile defense systems, jet fighter engines and other aircraft components (p. 4).

\section{Industrial and Medical Applications}

Rare earth elements are also used in wide range of high tech medical equipment and industrial machinery. Devices such as Magnetic Resonance Imaging devices (more commonly referred to as MRIs), Positron Emission Tomography Scanners (or PET scanners) and catalytic crackers used for petroleum refining in the oil industry rely on rare earth metals for proper functioning. Some additional applications of rare earth elements include its use in ceramics, automotive catalytic converters and glass polishing.

\section{DEMAND STATISTICS}

As the demand for the technologically advanced and environmentally friendly products and applications that require rare earth minerals increase, so too is the demand for the minerals expected to increase. The Congressional Research Service projects that demand for permanent magnets will grow by $10 \%-16 \%$ annually for the next two years. Within the same time period, the demand for rare earth metals in auto catalysts and petroleum cracking catalysts is forecasted to grow between $6 \%$ and $8 \%$ per annum, while the demand for rare earths in hybrid vehicle engines, flat panel display screens and defense systems are also expected to be on the rise (Humphries, 2010).

\section{Global Demand}

Table 1 shows the most recent world production statistics for various producers of REEs on a per country basis. According to the Congressional Research Service world demand exceeds total world production of 124,000 tons annually by approximately 10,000 tons per annum. Accumulated stockpiles of previously mined rare earth metals currently provide for this deficit. Global demand for REEs is expected to increase from the current 134,000 tons per year to approximately 180,000 tons per year by 2012 with a possible increase to over 200 thousand tons annually by the year 2014 (Humphries, 2010). 
Table 1

World Mine Production And Reserves

Data in metric tons of rare-earth oxide (REO) content

\begin{tabular}{|c|c|c|c|}
\hline & \multicolumn{2}{|c|}{ Mine production $^{\mathrm{e}}$} & \multirow[t]{2}{*}{ Reserves $^{1}$} \\
\hline & $\underline{2008}$ & $\underline{2009}$ & \\
\hline United States & - & - & $3,000,000$ \\
\hline Australia & - & - & $5,400,000$ \\
\hline Brazil & 650 & 650 & 48,000 \\
\hline China & 120,000 & 120,000 & $36,000,000$ \\
\hline Commonwealth of Independent States NA & NA & $9,000,000$ & \\
\hline India & 2,700 & 2,700 & $3,100,000$ \\
\hline Malaysia & 380 & 380 & 30,000 \\
\hline Other countries & NA & NA & $22,000,000$ \\
\hline World total (rounded) & 124,000 & 124,000 & $99,000,000$ \\
\hline
\end{tabular}

${ }^{\mathrm{e}}$ Estimated. NA Not available. W Withheld to avoid disclosing company proprietary data. - Zero.

${ }^{1}$ That part of the reserve base which could be economically extracted or produced at the time of determination. The term reserves need not signify that extraction facilities are in place and operative. Reserves include only recoverable materials.

Source: Salazar, K., \& McNutt, M. K. (2010). Minerals Commodity Summaries 2010. Washington: United States Government Printing Office, 129.

\section{U.S. Demand}

The 2008 apparent consumption of REEs in the United States (excluding thorium ore) was approximately 7410 metric tons, a decline from the 10,250 metric tons consumed the previous year. Apparent consumption was further decreased in 2009. These decreases were attributed to the worldwide economic recession which reduced demand of rare earth minerals for most applications according to the United States Geological Survey (2010). However the USGS still posits that the "trend is for a continued increase in the use of rare earths in many applications, especially automotive catalytic converters, permanent magnets, and rechargeable batteries for electric and hybrid vehicles" (Salazar \& McNutt, 2010). Table 2 below shows rare earth statistical data for the United States as well as world production data over a twenty year period.

\section{Demand Outside the United States}

China, the world's largest producer of rare earth minerals, is also the world's largest consumer. Molycorp Minerals (2009), a rare earth company based in the United States, reports that China currently mines over 120,000 tons of rare earth minerals and consumes approximately $60 \%$ of its production, a consumption rate that is rapidly increasing. According to Molycorp, "some leading experts project that by 2012 China's internal consumption of critical rare earth materials will rise to meet or exceed their production" (Molycorp Minerals , 2009).

Outside of the United States and China, Japan is the third most significant user of the rare earths which it incorporates into a variety of products.

\section{SUPPLY OF RARE EARTH ELEMENTS}

At present China is the largest producer of Rare Earth elements in the world, mining approximately 95\% of total world production. Consequently, many countries around the world, including the United States and Japan, both directly and indirectly rely on imports of these REEs from China to facilitate production of the various systems and products that are reliant on rare earths as raw material. For example, Japan relies on imports from China to produce the rechargeable batteries used to power the hybrid vehicles and several other products that it exports to the United States and other countries. It is not unreasonable to assume that a contraction in the global supply of rare earth minerals can adversely affect the gross domestic product of nations like Japan. 
Table 2

Rare Earths Statistics

\begin{tabular}{|c|c|c|c|c|c|c|}
\hline Year & Production & Imports & Exports & $\begin{array}{c}\text { Apparent } \\
\text { consumption }\end{array}$ & Unit value (\$/t) & World production \\
\hline 1989 & 20,800 & 7,710 & 1,940 & 27,800 & 6,780 & 60,700 \\
\hline 1990 & 22,700 & 5,520 & 5,860 & 28,700 & 8,990 & 52,900 \\
\hline 1991 & 16,500 & 5,930 & 5,360 & 22,100 & 9,470 & 41,700 \\
\hline 1992 & 20,700 & 5,110 & 5,720 & 21,400 & 10,100 & 50,100 \\
\hline 1993 & 17,800 & 6,250 & 7,170 & 17,000 & 9,010 & 46,700 \\
\hline 1994 & 20,700 & 6,990 & 10,200 & 17,800 & 7,980 & 55,100 \\
\hline 1995 & 22,200 & 12,400 & 10,600 & 24,000 & 8,210 & 74,300 \\
\hline 1996 & 20,400 & 17,500 & 13,000 & 24,900 & 7,150 & 79,700 \\
\hline 1997 & 20,000 & 12,200 & 12,400 & 19,400 & 8,540 & 68,300 \\
\hline 1998 & 10,000 & 14,000 & 9,440 & 11,500 & 8,900 & 77,100 \\
\hline 1999 & 5,000 & 21,300 & 9,620 & 11,500 & 6,400 & 86,600 \\
\hline 2000 & 5,000 & 21,700 & 9,750 & 12,100 & 6,450 & 90,900 \\
\hline 2001 & 0 & 19,200 & 9,100 & 10,100 & 5,790 & 94,500 \\
\hline 2002 & 0 & 14,200 & 8,210 & 5,990 & 7,500 & 98,200 \\
\hline 2003 & 0 & 16,700 & 7,310 & 9,390 & 6,150 & \\
\hline 2004 & 0 & 17,300 & 11,800 & 5,500 & 8,590 & 97,100 \\
\hline 2005 & 0 & 15,300 & 9,240 & 6,060 & 6,595 & 102,000 \\
\hline 2006 & 0 & 18,500 & 9,150 & 9,350 & 3,890 & 122,000 \\
\hline 2007 & 0 & 17,700 & 7,450 & 10,250 & 5,290 & 137,000 \\
\hline 2008 & 0 & 15,300 & 7,920 & 7,410 & 12,100 & 124,000 \\
\hline S6 & 0 & 1500 & 134,000 \\
\hline
\end{tabular}

Source: Hendrick, J. B., \& DiFrancesco, C. A. (2009). Rare Earths Statistics. U.S. Geological Survey

\section{China's Current Dominance}

As noted in a previous section, rare earth metals are not as rare as its name implies. They are reasonably abundant in the earth's crust, even. Thus, the fact that China mines virtually all of total global production is not an indication that the majority of rare earth elements are located in that part of world. As a matter of fact, from as early as 1953, the United States was the major producer of rare earth elements before suspending operations at its 55 acre mine at Mountain Pass, California in 1998 (Jenkins, 2010). The chart in Figure 2 shows that the United States has become almost fully reliant on Chinese imports.

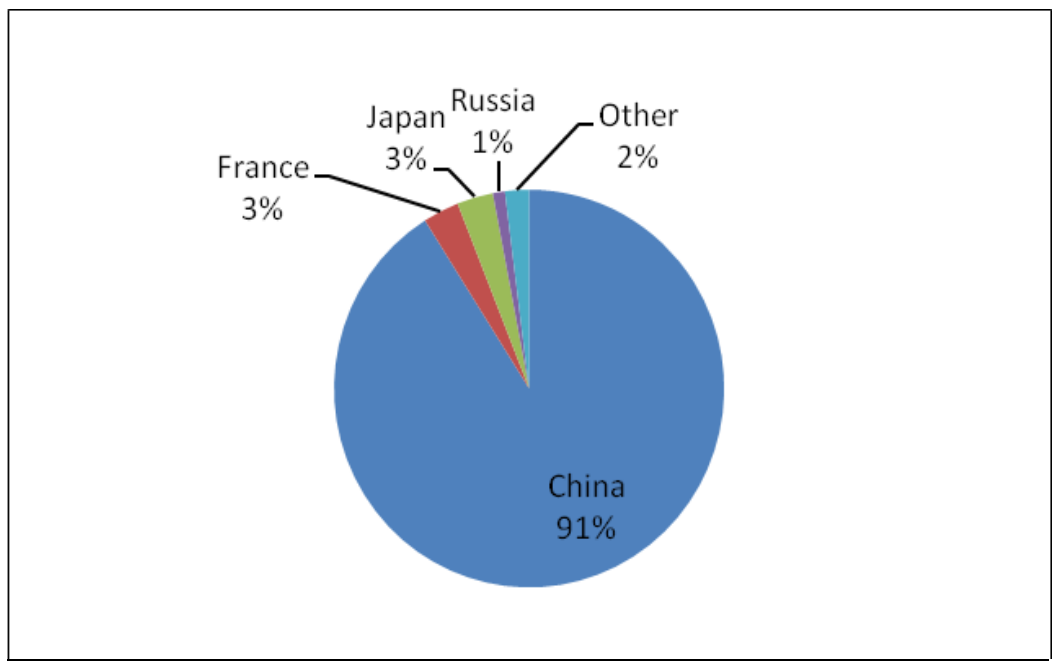

Figure 2

US Sources Of Rare Earth Material Imports (2005-2008)

Source: Salazar, K., \& McNutt, M. K. (2010). Minerals Commodity Summaries 2010. Washington: United States Government Printing Office, 128. 
China has managed to capitalize on the rare earth element industry by developing the resources (technology, techniques and an experienced labor force) required to efficiently and effectively mine, extract, separate and refine rare earth minerals at more operationally feasible costs than other countries. As a result, it became more economically viable for countries, such as the United States, to cease production of rare earth minerals and import them from China. This operational efficiency has caused China to effectively emerge as the leading supplier of rare earth minerals to an extent that could be easily equated to a monopoly. The fact that China controls the global supply of rare earth metal allows the country to effectively control quality, quantity and ultimately the prices of these rare earth elements through export quotas and trade tariffs.

\section{SUPPLY CHAIN RISKS}

\section{The Dependability of the Supplier}

There are several supply chain risks inherent in a global market wherein the supply of virtually all of a raw material critical to the development of many products is largely controlled by one supplier. At present, "both production of rare earth materials in China and export of those materials outside of China are strictly controlled by government imposed quotas" (Molycorp Minerals, 2009). Japan, a country that manufactures and exports many products that use rare earth metals, was exposed to and negatively impacted by one such risk. In September 2010, China placed what seemed to be an unannounced and unofficial embargo on the export of rare earth metals to Japan - a claim that was repeatedly denied by the Chinese government (Humphries, 2010). An incident that was initially thought to be related to longstanding maritime wars between China and Japan was heightened when China subsequently began halting exports to other countries as well. China's export quotas continued to be reduced in 2011 and this has created significant upward price pressure on many of the scarce metals.

Moreover, in August, 2011, China announced the shutdown of it rare earth operations for a three-month period, allegedly to address serious environmental issues. Rare earth mining is notorious for its air and water pollution as well as its toxic, radioactive residues. Chinese officials cited the need to install pollution control equipment in many of the small, private companies that often ignored these concerns. By invoking environmental concerns, China hoped to circumvent World Trade Organization prohibitions against trade restrictions on vital materials (Bradsher 2011). These incidents have led many governments around the world to question China's reliability as a supplier of the critical rare earth minerals and have fuelled the urgency of nations to curtail China's monopoly on the rare earth metal industry.

\section{Resource Constraints}

Although China produces and refines over $95 \%$ of the world's rare earth metal supply, the country possesses a relatively small proportion (approximately 34\%) of the 99 million tons of the world's reserves. World reserves refer to the amount of rare earth minerals in the earth's surface that can be economically extracted from mines if the requisite resources and materials were made available to do so. Table 2 above shows the most recent data on reserve quantities for various countries. From this table we observe that those countries such as India, Australia and even the United States each have millions of tons of rare earth resources available, presumably enough to satisfy each country's own demand.

Many experts argue that there are sufficient world reserves to meet the forecasted increases in consumption for the foreseeable future (Hendrick \& Cordier, 2010). However, the abundance of rare earth mineral reserves does not seem to be enough to mitigate the current state of crisis regarding an impending supply shortage. This is because no matter how abundant world reserves are, without the necessary resources to extract the raw materials from the ground and with continued reliance on a China as the dominant source of supply, production will neither be able to meet nor sustain anticipated future demand.

\section{Excessive Reliance on a Single Supplier}

Despite the recent impediments placed on Japan and other countries and the state of emergency placed on the situation by several nations, the contraction of supply of rare earth materials by China is neither a new nor 
shocking issue. In her 2010 article, Hunt states that "experts have been warning of the dangers of U.S. reliance on Chinese rare earths for many years" (p.2). This assertion came subsequent to announcements of decreases in exports of rare earth minerals by Chinese officials. To further exacerbate the concerns of many nations, approximately three months before the apparent embargo placed on Japan, China imposed export restrictions on rare earths that resulted in a supply shortage for countries outside of China. In July 2010, "China announced that it will cut exports this year of rare-earth elements (REE) by $40 \%$, leaving demand outside China exceeding the supply for the first time ever" (Service, 2010a).

There are several reasonable assumptions and theories that seek to explain why China would be inclined to restrict exports to other countries. The most evident reason is that as China's demand for rare earth dependent technologies such as cell phones, computers, and flat panel displays screens increase, the country's own demand for rare earth elements is quickly outgrowing its supply. Therefore, the imposition of export restrictions may not be a malicious attempt by the Chinese government to "starve the world of rare earth metals" (Jenkins, 2010), but may be considered necessary to make the metals more readily available for domestic consumption.

Another theory that has surfaced to explain why China may be impelled to reduce export quotas is the country's possible attempt to stimulate its own economy by increasing domestic production of those products like rechargeable batteries and flat panel screens that are currently dominated by other countries such as Japan and India. Therefore, imposing such restriction on supply inevitably increases the company's competitive advantage for sale of these products. This theory was reinforced by Eggert (2010), professor and director of the Division of Economics and Business at the Colorado School of Mines, who argues that "when China restricts exports of a primary raw material, such as rare-earth elements, it presumably is doing so to create an advantage for those manufacturing industries that use rare earths domestically in goods that will be sold both domestically and internationally" (p. 56).

\section{The Limitations of Supply Diversification}

An obvious way to reduce the supply risks associated with the current rare earth metal industry is to diversify production outside of China. However, there are several limitations associated with supply diversification in this industry.

The same reasons that most countries opted to rely on imports from China in the first place may prove to be the identical reasons that may make it economically impractical to expand production facilities globally - that is, the low cost of operations that currently exists in China. Eggert (2010) acknowledged this likelihood when he pointed out that "the biggest impediment to the opening of rare-earth mines outside of China is the reality that China is and likely will remain the low-cost producer of rare earths worldwide and probably could supply most world demand at prices lower than those necessary to justify new mines" (p. 53).

In addition, it would be difficult for other countries to secure the necessary expertise, such as chemical engineers, in the short period of time required to meet increasing demand. Karl A. Gschneidner Jr., senior metallurgist and one of the world's leading rare-earth experts told Congressional panellists in March 2010 that "rareearth research in the United States on mineral extraction, rare earth separation, processing of the oxides into metallic alloys and other useful forms, substitution, and recycling is virtually zero" (Ingebretsen, 2010). This "shortage of talent" as Ingebretson calls it, would negatively impact attempts by the United States and other countries to diversify production and reduce the monopolistic control of the industry by China.

Nevertheless, given the global supply situation, we are seeing various countries ramp up production of the rare earth elements. It remains to be seen if these initiatives can have much of an impact on China's dominant global position in the market for the rare earth elements.

\section{ACKNOWLEDGEMENT}

The significant contribution of research assistant, Genai Greenidge, is gratefully acknowledged. 


\section{AUTHOR INFORMATION}

Joseph A. Giacalone, Ph.D., is Professor of Economics and Holder of the Henry George Chair in Economics, St. John's University, USA. Dr. Giacalone earned his B.A. and Ph.D. at Columbia University and his MBA at St. John's University. He previously served fifteen years as Associate Dean and four years as Dean of the College of Business Administration. His publications are in the areas of health care economics, business and economic history, economic thought, industry studies, and collegiate business education. E-mail: giacaloj@stjohns.edu

\section{REFERENCES}

1. $\quad$ Bourzac, Katherine (2011). The Rare Earth Crisis. Technology Review. May-June, 58-63.

2. Bradsher, Keith (2011). China Consolidates Grip on Rare Earths. September 16, Retrieved from NYTimes.com http://www.mytimes.com/2011/09/16/business/global/china-consolidates-control-of-rareearths

3. Eggert, R. G. (2010). Critical Minerals and Emerging Technologies. Issues in Science and Technology, 5356. Retrieved from Academic Search Premier database.

4. Hendrick, J. B., \& Cordier, D. J. (2010). 2008 Minerals Yearbook: Rare Earths. U.S. Department of Interior, U.S. Geological Survey: http://minerals.usgs.gov/minerals/pubs/commodity/rare earths/myb12008-raree.pdf

5. Hendrick, J. B., \& DiFrancesco, C. A. (2009). Rare Earths Statistics. U.S. Geological Survey: http://minerals.usgs.gov/ds/2005/140/

6. Humphries, M. (2010, September 30). Rare Earth Elements: The Global Supply. Retrieved November 5, 2010, from Federation of American Scientists: http://fas.org/sgp/crs/natsec/R41347.pdf

7. Hunt, M. W. (2010). Rare Earth Dearth. Advanced Materials and Processes, 2. Retrieved from Academic Search Premier database.

8. Ingebretsen, M. (2010). The Global Rare-Earth Race. Advanced Materials and Processes, 24. Retrieved from Academic Search Premier database.

9. Jenkins, S. (2010). Rare-Earth Metals for the Future. Chemical Engineering , 17-18,20,22-23. Retrieved from ABI/INFORM Global. (Document ID: 2181276671)

10. Molycorp Minerals . (2009). Global Outlook. Retrieved November 5, 2010, from Molycorp Minerals: The Rare Earth Company: http://www.molycorp.com/globaloutlook.asp

11. Salazar, K., \& McNutt, M. K. (2010). Minerals Commodity Summaries 2010. Washington: United States Government Printing Office: ttp://minerals.usgs.gov/minerals/pubs/mcs/2010/mcs2010.pdf

12. Service, R. F. (2010a). Chinese Policies Could Pinch U.S. Efforts to Make Electric Vehicles. Science, 329 (5990), 377. Retrieved from Academic Search Premier database.

13. Service, R. F. (2010b). Nations Move to Head Off Shortages of Rare Earths. Science, 327, 1596-1597. Retrieved from Academic Search Premier database. 